\title{
Analyzing key influences of tourists' acceptance of online reviews in travel decisions
}

\author{
Authors: \\ Alain Yee Loong Chong, Kok Wei Khong, Teng Ma, Scott McCabe, Yi Wang
}

Journal: Internet Research

Purpose

This study aims to examine what influence travelers' adoption of online reviews, and whether the online reviews will influence their travel planning decisions.

\section{Design/methodology/approach}

Data was collected from 193 respondents from eWOM websites and analyzed using structural equation modeling.

\section{Findings}

Our results revealed that eWOM has a significant influence on travel decisions. Furthermore, travelers were willing to adopt information from eWOM and this information was useful in their travel planning and decisions. Gender and time spent on online reviews were found to affect travel planning and decisions. Travelers also found that the reviews and issues raised in eWOM had credibility and were of good quality.

\section{Research limitations/implications}

Our study was not able to incorporate all factors which may be relevant to this study and so further theoretical development may be necessary to develop the conceptual model. The sample size, while adequate, can be expanded further.

\section{Practical implications}

Operators and administrators of eWOM can use these findings to develop more userfriendly interfaces so that more positive reviews and sales can be generated.

\section{Social implications}

Our results showed that travelers who adopt the information in eWOM will, in turn, use eWOM in their travel planning. This confirms the importance of eWOM and travelers in general will translate their pre-travel decisions into actual travel planning.

\section{Originality/value}

This research extended existing eWOM and information system adoption studies and focused on the travel planning context. This research validated the significant roles of eWOM argument quality and credibility in predicting the information usefulness of eWOM.

Keywords: Electronic word-of-mouth; Travelers; Technology Acceptance Model; Information Adoption Model; Elaboration Likelihood Model; Online Reviews 


\section{Introduction}

Information is the bedrock upon which tourism is built, and the role of information technology has long been recognized within the tourism academy (Capriello et al., 2013; Vallespín et al., 2017). One of the most important consequences of the development of the Internet in the context of tourism information provision is the widespread appeal of electronic word-of-mouth (eWOM), which is stimulated by the popularity of social network websites and mobile applications (Capriello et al., 2013; Gvili and Levy, 2016). Word-of-mouth (WOM) has long been considered as a vital external information source for travel-related product purchases and decision-making. In contrast to offline WOM, eWOM provides a persistent public record online so that the information is not ephemeral but leaves a permanent record (Yang et al., 2012). The emergence of eWOM in the travel and hospitality industry has seen a growth in the popularity of travel portals such as tripadvisor.com and ctrip.com. As third-party opinion platforms, they have amassed a wealth of travel information, and have established themselves as important avenues for eWOM by allowing users to interact and provide reviews on restaurants, hotels, or local tourist attractions. The fast-spreading popularity of eWOM in tourism has resulted in increasing interest in research in this area.

The early stage of eWOM research in tourism was more focused on how eWOM has become the main source of information for travelers when making travel plans (Gretzel and Yoo, 2008; Litvin et al., 2008; Vermeulen and Seegers, 2009). This was followed by studies on eWOM-related consumer behavior (Casaló et al., 2010). The most recent research has become more in-depth and more diverse. Generally, these studies can be divided into four types: research focused on the senders' perspective; tourism managers' perspective; eWOM third parties' (such as TripAdvisor) point of view; and finally research from the eWOM users' point of view.

The paper focuses on the fourth type which is eWOM from the adopters'/users' perspective. Papathanassis and Knolle (2011) and Ayeh et al. (2013) all aimed to develop conceptual models in order to test different variables in eWOM that affect travelers' travel decisions. Whilst these studies have made important steps forward in our understanding of the influence of eWOM on travel decision making, there is much further development of both theoretical and empirical based models required to gain a deeper appreciation of the nature and extent of this influence. For example, these models and the various constructs did not explain what kind of review information might be adopted in travel planning. Additionally, categorical dimensions like gender and time spent on online reviews may present important relevance as to how review of information is assessed in travel planning. Thus, we still have little knowledge about which aspects of information credibility or argument quality within eWOM reviews influence the usefulness of eWOM reviews. In addition, there are few studies that have examined whether the adoption of eWOM information will lead to the integration of eWOM in actual travel planning. These questions provided the impetus for this study, which aims to bridge this gap in the existing literature. Previous information systems' acceptance studies have applied various theories such as the theory of planned behavior, innovation diffusion theory, and other motivation theories. Among these theories, the technology acceptance model (TAM) (Davis, 1989) is the most prevalent and preferred model among them (Lin, 2007; Venkatesh and Speier, 1999). However, given the discrete nature of online reviews in tourism sectors as well as the high involving task of travel planning, TAM might not offer sufficient understanding of users' attitudes and 
intentions. Thus, researchers in the past often extended TAM to get a better understanding of consumers' decisions in their adoption of information systems. One good example is the Information Adoption Model by Sussman and Siegal (2003) which integrates TAM with the ELM model. In their information adoption model, they argued that by integrating TAM with the ELM, it is suggested that the argument quality and credibility of a message will be an important antecedent of usefulness (Sussman and Siegal, 2003). Following the similar path, the theoretical basis of this study integrates TAM (Davis, 1989), ELM (Petty and Cacioppo, 1986; Petty et al., 1983) and the Information Adoption Model (Sussman and Siegal, 2003). It is through this more holistic approach that a fuller appreciation of the subtleties of eWOM adoption and usefulness can be gleaned. This study primarily looked at the consumption of online information of the Chinese tourists due to their high online adoption rate. Chinese users tend to use online information to assess the service quality, satisfaction and experiences of holiday trips, accommodations, site attractions, travel activities and dining via reviews (Yang et. al, 2015). These information-adoption behavior spans from domestic to international travels. We believe that the sample from this population will provide reasonable evidence to explain tourists' acceptance of online reviews in travel decisions.

\section{Theoretical background and research hypotheses}

\section{$2.1 e W O M$}

WOM refers to interpersonal communications among consumers concerning their personal experiences and evaluations of a firm or a product (Richins, 1983). Consumers tend to rely on WOM to reduce the level of perceived risk and uncertainty (Klein, 1998). In the Internet era, the effects and distribution of WOM have been further enhanced since personal recommendations are made massively available on an impersonal basis (Zhou et al., 2017). Yet, the impersonal nature of the information provided does not appear to have impacted negatively on its potential use by others in the tourism domain. eWOM is defined by Hennig-Thurau et al. (2004) as any type of positive or negative comment or statement by potential, former, or current customers about a product, service or company, which is made available to all users via the Internet. eWOM has become very popular in recent years due to the increasing number of contributors as well as the rise of mobile platforms for social media applications (Lu et al., 2013; Lee, 2007). EWOM has also had a significant impact on the travel industry. It is considered as an important information source influencing tourists' travel intention and choice of destination (Grewal et al., 2003; Soderlund and Rosengren, 2007). TripAdvisor.com reported that each year hundreds of millions of potential visitors consult online reviews (Tripadvisor.com, 2011). EWOM is a form of online user-generated content (UGC), which enables users to share interesting or unique experiences (Tsao et al., 2015; Kwon et al., 2017). Notwithstanding the potential for bias, this free information assists readers to understand new destinations, activities, and sensitive topics (Grewal et al., 2003; Soderlund and Rosengren, 2007). Gretzel and Yoo (2008) further found that readers often find online reviews provided by other travelers are more up-to-date, enjoyable, and reliable than information provided by travel service providers.

Although the importance of eWOM in influencing travelers' decision-making is recognized, research on how and why travelers adopt review contents in travel planning is limited (Chong and Ngai, 2013). One relevant study is by Ayeh et al. (2013), who examined various factors such as perceived enjoyment, attitudes, perceived usefulness, 
examining how they influence consumers' decisions to plan trips based on eWOM. However, their study chose to focus on consumer-generated information, rather than review contents. Their constructs include enjoyment, ease of use, similarity of interest, trustworthiness, attitude and intention, which do not cover any variables evaluating the quality of review contents. It is important to understand what influences the adoption of eWOM information in the context of travel planning, and whether the adoption of the information will influence the travel planning decisions remain sparse. Furthermore, there is little examination into the specific measurements of eWOM argument quality and credibility, and how these affect the usefulness of review information. Despite the popularity of eWOM, our current understanding of how travelers process eWOM reviews are still limited (Xie and Boush, 2011).

\subsection{TAM}

Technology adoption theories have focused on understanding how people decide to accept a new technology for the first time. One of the most popular and influential technology adoption models is the TAM (Teo et al., 2007; Muk and Chung, 2014). TAM has been examined in various information system models such as e-commerce, mobile commerce and social media tools (Chong et al., 2012). TAM is predicated on the notion that perceived ease of use and perceived usefulness are two key variables that can capture all the relevant beliefs in the information systems usage context (Davis, 1989). Despite its popularity, TAM has been criticized for being too simplistic in its efforts to understand users' motivations in adopting technology. In particular, one view of TAM is that it has now been studied so extensively that researchers now believe that there is almost no denying the fact that perceived usefulness and perceived ease of use both have an important influence on users' decisions to adopt information technology (Benbasat and Barki, 2007). Despite these criticisms, TAM remains a good theoretical based model for users to build their research model on due to its simplicity and its relevance in different types of information systems adoption studies, and indeed in its widespread acceptance amongst researcher communities. Models such as TAM2 (Gefen et al., 2003), TAM3 (Venkatesh and Bala, 2008), Unified Theory of Acceptance and Use of Technology (UTAUT) (Venkatesh et al., 2003) and UTAUT2 (Venkatesh et al., 2012) have all been developed and using the theoretical foundations of TAM.

Perceived usefulness is the degree to which the users believe that the information system will enhance his or her work. Perceived ease of use is the degree to which users believe that using the information system will be free from effort (Davis, 1989). Past studies have confirmed the importance of these two variables in the context of technology adoption in the hospitality and tourism industry (Ayeh et al., 2013; Oh et al., 2013; Casaló et al., 2010). In the current study, perceived usefulness is the belief of users that the review information in eWOM is helpful in their travel planning. Perceived ease of use is the belief that eWOM review information requires minimum effort for them to use and understand. For example, in eWOM for travel planning, there are rating scores or stars, the number of 'likes' on the reviews, etc., and users may need to understand what they mean. Similar to the original TAM model, we also proposed that if the eWOM information were easy to use and understand, potential travelers would find it more useful. As such, perceived usefulness also has a mediating effect on perceived ease of use and the adoption of information. Based on the discussions, the following hypotheses are proposed: 
H1a: Perceived Usefulness of eWOM is positively associated with information adoption.

H1b: Perceived Usefulness of eWOM mediates the relationship between Ease of Use and Information Adoption

H2a: Perceived Ease of Use of eWOM is positively associated with Perceived Usefulness of eWOM.

$\mathrm{H} 2 \mathrm{~b}$ : Perceived Ease of Use of eWOM is positively associated with Information Adoption

\subsection{Information Adoption Model}

TAM has also been applied in understanding how users adopt information. Information adoption is a process in which users engage in using information(Sussman and Siegal, 2003). These authors integrated TAM with the ELM to develop the information adoption model to understand how users adopt information. We used both seemingly disparate models to address the phenomenon in how users adopt information. Using this approach, we explore how the implicit assumptions of ELM from the eWOM perspective complement TAM from an information adoption perspective (Mayer and Sparrowe, 2013). The synthesis of ELM and TAM begins with ELM stating that users' perceived usefulness of the information is influenced by the eWOM's argument quality and credibility. Although the information adoption model is able to explain why users adopt information, questions as to what aspects of eWOM credibility and the quality of the argument have not previously been investigated. Therefore, TAM addresses this with its dimensions on information adoption and intention to use eWOM for travel planning. Both the ELM and information adoption model have been shown to be effective in predicting information adoption in the information systems field (Cheung et al., 2008; Cheung et al., 2012). Yet, their applications in tourism are rare. The next section provides an overview and definitions of eWOM argument quality and credibility.

\subsection{1 eWOM argument quality and credibility}

According to the ELM, either a central or peripheral route can influence an individual's attitudes. An individual taking the central route will think critically about issues that are related to the arguments and scrutinize the quality of the arguments before forming an attitude about a particular product or advertisement (Sher and Lee, 2009; Owusu et al., 2016; Zhou, 2017). Thus, the ELM argues that when a consumer is able and willing to "cognitively elaborate on a persuasive communication, the quality of the arguments contained within the communication will determine the degree of informational influence" (Sussman and Siegal, 2003). Social psychology research has supported the view that the quality of argument in a message has a greater influence on persuasion (Petty et al., 1983).

On the other hand, an individual taking the peripheral route is likely to be influenced by the informational indicators as opposed to the review content (Sussman and Siegal, 2003). Thus, an individual, who takes the peripheral route, when deciding on whether he or she accepts a given message, will rely on the environmental cues of the message instead of scrutinizing the eWOM argument. Similar to Sussman and Siegal's (2003) Information Adoption Model, the argument quality of the eWOM is considered as a 
central influence while the eWOM credibility is considered as a peripheral influence. According to the ELM and the Information Adoption Model, eWOM's argument quality and credibility have a strong influence on the adoption of review information (Chan and Ngai, 2011; Cheung et al., 2008; Cheung et al., 2009; Petty and Cacioppo, 1986; Sussman and Siegal, 2003).

Argument quality is defined as the persuasive strength of arguments in the eWOM reviews (Bhattacherjee and Sanford, 2006). In the present study, argument quality manifest influences on eWOM's review timeliness, review accuracy, review comprehensiveness, argument strength, review relevance, review framing, recommendation sidedness and confirmation of prior belief (see defining the measures of the constructs section for more details). Based on past literature which adopted the integrated models, the quality of argument (information) is evaluated in terms of the information content, accuracy, format, and timeliness (McKinney et al., 2002). Credibility in this study is defined as the extent to which travelers perceive the eWOM as being believable and truthful (Tormala and Petty, 2004; Cheung et al., 2009). Consistent with previous eWOM studies, the assessment of credibility in this research is based on the eWOM review content, rather than on the trust of a person or the travel company (Cheung et al., 2009; Xie and Boush, 2011).

Credibility of eWOM has long been an interest of persuasion research, and reviews with high credibility are often found to be more persuasive than those with low credibility (Petty and Wegener, 1998; Tormala and Petty, 2004; Lin and Xu, 2017). Existing literature mainly focuses on expertise and trustworthiness of information source. Some scholars used source credibility to measure information source's expertise and trustworthiness. However, in an online environment, where social cues such as gender, age, social and professional status are not rich, it is difficult to determine the information source's expertise, trustworthiness. Therefore, new constructs may be in need to measure the source credibility. Perceived credibility of eWOM in this study manifest influences on the reviews' source credibility, source expertise, source trustworthiness, review consistency and ratings of the review. The constructs for these studies are adopted from existing studies such as those from Cheung et al. (2009).

As discussed in the earlier section on TAM, researchers have in the past extended TAM in order to better understanding consumers' decisions in their adoption of information systems. One piece of research that has integrated TAM with the ELM is the Information Adoption Model by Sussman and Siegal (2003). Sussman and Siegal (2003) in their information adoption model, argued that an individual's adoption of information based on TAM would be the extent to which they believe the information is useful. By integrating TAM with the ELM, it is suggested that the argument quality and credibility of a message will be an important antecedent of usefulness (Sussman and Siegal, 2003). The discussions above help us to establish the connections between the argument quality and credibility of eWOM and usefulness of the eWOM review. These relationships are examined in a tourism context (e.g. travel planning decision) in this research. Using the information adoption model, we develop the following hypotheses:

H3: $\quad$ eWOM argument quality is positively associated with perceived usefulness of eWOM. 
H4: eWOM credibility is positively associated with perceived usefulness of eWOM.

\subsection{Information adoption and Intention to use eWOM for Travel Planning}

Although travelers, when viewing eWOM, may decide to adopt eWOM information, little is known as to whether they will then plan their travels based on the eWOM information. Essentially, little is known from existing literature on the connections between eWOM information adoption and using the information in travel planning. As a result, it is possible that travelers, when viewing eWOM, agree with the reviews from the system. However, will they then really follow the reviews and book or plan their travel destinations based on this information? Zhang et al. (2014) and Cheung and Thadani (2012) in their review of existing studies on eWOM stated that the purchasing intentions (similar to use of eWOM for travel planning in the context of this study) and eWOM adoption are two of the most popular response variables. However, they found that the interrelationships between these variables had not been fully studied. Accordingly, we propose that travelers do indeed translate the adoption of eWOM into tangible action, which means that they use eWOM in their travel planning, and propose the following hypothesis:

H5: Information Adoption is positively associated with Intention to use eWOM for travel planning.

Based on the discussions above, Figure 1 shows the research model proposed for this study.

<Figure 1 Research Model>

\subsection{Defining the measures of the Constructs}

\subsubsection{Argument Quality}

There are several measurements of the quality of an argument in an eWOM review. Based on a review of existing literature, this research developed its measurement items for argument quality based on eight constructs and 23 items, e.g. an eWOM's review timeliness, review accuracy, review comprehensiveness, argument strength, review relevance, review framing, review sidedness and confirmation of prior belief. All measurement items used in this study are adopted from previous literature (e.g. Chong and Ngai, 2013; Cheung and Thadani, 2012; Cheung et al., 2009; Sussman and Siegal, 2003; Cheung et al., 2008).

Review timeliness refers to whether the reviews on eWOM are current. With the Internet, the reviews on eWOM could have been conducted months or even years ago. Therefore, as a traveler, they are more likely to believe in the review's argument quality if these reviews are up to date. Review accuracy is defined as to whether the review contents in the eWOM are reliable. It is also the travelers' perceptions as to whether the 
eWOM reviews are correct (Chong and Ngai, 2013; Cheung and Thadani, 2012). The comprehensiveness of the review refers to whether the eWOM reviews are complete (Cheung and Thadani, 2012). Argument strength in this research is the extent to which the traveler views the arguments in eWOM as convincing or valid in supporting its positions (Chong and Ngai, 2013). Relevance refers to whether the eWOM reviews are applicable and useful for travelers in their travel planning decisions (Cheung et al., 2008). Review framing defines the valence of the eWOM reviews (Cheung et al., 2009). Thus, a message, depending on whether it is positively framed or negatively framed, may have an influence on the eWOM review's argument strength. Review sidedness refers to whether a message is two-sided (e.g. containing both positive and negative messages). Marketing researchers have found that having only one-sided messages may increase the skepticism of users, while users are more convinced by arguments which contain both positive and negative messages (Belch, 1981). Lastly, confirmation of prior beliefs is defined as the level of confirmation and disconfirmation between the review information from eWOM and a user's prior beliefs on the products or services (Cheung et al., 2009). This is also supported in the study by Zhang et al., (2014), where past experiences of reading reviews and perceptions that formed after visiting the sites was an important element in formulating the online reviews decision-making model.

\subsection{2 eWOM credibility}

EWOM credibility is a multi-dimensional scale measured by five constructs and 14 items, e.g. the source credibility, source expertise, source trustworthiness, review consistency and review rating. All measurement items are adopted from previous literature (e.g. Chong and Ngai, 2013; Cheung and Thadani, 2012; Cheung et al., 2009; Sussman and Siegal, 2003; Cheung et al., 2008).

In eWOM, other users, such as administrators, other reviewers or visitors to the eWOM system who can rate the reviews, can determine a reviewer's reputation for credibility (Cheung et al., 2009). Similar to Cheung et al. (2009), this research used the source (reviewer) credibility as a measurement of the credibility of the eWOM. Source expertise in this research is defined as travelers' perceptions of the reviewers' knowledge, competence and authority in the subject matter (Cheung and Thadani, 2012). Source trustworthiness is defined as the reviewer's motivation to provide truthful information (Chong and Ngai, 2013). One potential issue faced by eWOM is that reviewers may not be motivated to provide truthful information. For example, a reviewer could be a competitor of a business, thus may leave negative reviews on eWOM. A recent study also found that sometimes users are being asked or even paid to change their reviews from negative to positive comments, such as in the case of the popular Chinese e-commerce website Taobao (Chong and Ngai, 2013). Given that eWOM has reviews by different reviewers, users may feel that reviews to be more credible if their review comments are consistent. As stated by Cheung et al. (2009), users are more likely to believe in normative opinions. Lastly, review rating is the ratings given by other readers of the eWOM review. A reviewer's comments can receive good or bad ratings from readers, and those with high ratings will tend to be perceived to be more credible than those with low ratings (Chong and Ngai, 2013).

\subsubsection{Perceived Usefulness of eWOM, Perceived Ease of Use of eWOM, eWOM Adoption and Intention to use eWOM for Travel Planning}


A total of 13 items were used to measure Perceived Usefulness of eWOM, Perceived Ease of Use of eWOM, eWOM Adoption and Intention to use eWOM for Travel Planning. All items are adopted from previous literature (i.e. Ayeh et al., 2013; Cheung et al., 2009; Davis, 1989; Cheung et al., 2008). Based on the discussion, the following table depicts the list of items and measurement models.

\section{< Table 1 List of items and measurement models >}

\section{Methodology}

\subsection{Methodology and data analysis}

A series of statistical procedures and analyses were conducted on the dataset. Due to the complex nature of associations amongst the constructs in Figure 1, SEM was used. The observations of each construct manifested by indicators make SEM most suitable. Additionally, SEM also deals with the latent indicators associated with the construct. SEM has become one of the most common statistical analyses for social science studies where multiple regression equations are measured simultaneously (Hallak et al., 2012). As mentioned, SEM was particularly useful and practical as the multivariate associations amongst the constructs are complex.

In doing so, a two-step approach was used as recommended by Anderson and Gerbing (1988). First, a Confirmatory Factor Analysis (CFA) was conducted to evaluate the nature of the predefined constructs in the literature. The constructs are depicted in Figure 1. The endogenous constructs were Perceived Usefulness of eWOM, Perceived Ease of Use of eWOM, Information Adoption and Intention to use eWOM for Travel Planning while the remaining measurement models were exogenous constructs, i.e. eWOM Argument Quality and eWOM Credibility. In addition, the CFA will also involve second order factor analyses on the exogenous constructs of which the second order construct Argument Quality will be manifested by Relevance, Timeliness, Accuracy, Comprehensiveness, Argument Strength, Recommendation Framing, Recommendation Sidedness and Confirmation with Prior Belief while Source Credibility by Credibility, Source Expertise, Trustworthiness, Consistency and Rating. Then, the structural model analysis will be conducted to test the hypotheses stipulated in the literature.

\subsection{Sampling frame and data collection}

The target population for this research included individuals with Internet access, which take vacation trips on a regular basis. This is consistent with the approach taken by previous research (Ayeh et al., 2013). Our data were collected from Chinese travelers. An online survey was developed using Kwiksurveys (http://www.kwiksurveys.com). The survey was developed in English and translated into Chinese language. We pretested the survey with ten university students and two university professors who are familiar with the research topic. We posted the link to the instrument online at WeChat and Weibo, both popular Chinese social media platform, where the link is shared amongst social media users amongst the relevant travel network. The purpose of our research was explained to respondents, and they were then directed to popular Chinese travel websites (e.g. Qunar.com). We asked respondents if they have traveled within 
the last 12 months preceding the survey, and have used eWOM websites to obtain travel information. We asked them which websites they have used and only those who have used eWOM websites over the last 12 months were selected for this study. Respondents were asked to familiarize themselves with the content and respond to the survey accordingly. In total, 193 usable responses were collected for this study. The sample size was deemed sufficient to perform the necessary statistical procedures like Structural Equation Modeling (SEM) (Yap and Khong, 2006). Missing values, assumed to be missing at random from these responses were estimated using SPSS AMOS, which provided efficient and consistent estimate means and intercepts (Arbuckle, 2009). Table 2 summarizes the demographic profiles of our respondents.

\section{< Table 2 Profile of Respondents $>$}

\section{Results and Findings}

\subsection{Model fit-measurement models, second order factors and overall model}

The measurement models Review Relevance, Review Timeliness, Review Accuracy, Review Comprehensiveness, Argument Strength, Review Framing, Review Sidedness and Confirmation with Prior Belief were depicted to manifest the second order factor eWOM Argument Quality. Using SPSS AMOS, CFA was conducted to ascertain the model fit of this second order factor analysis. Results show that the $\chi^{2} \mathrm{p}$-value of model fit test for Argument Quality had a significance value above 0.05 implying that the model had a good fit. Similarly, the second order factor eWOM Credibility, manifested by Source Credibility, Source Expertise, Source Trustworthiness, Review Consistency and Review Rating, also presented a significance value above 0.05 indicating that the model had a good fit. Additionally, the model fit tests on Perceived Ease of Use of eWOM, Perceived Usefulness of eWOM, Information Adoption, Intention to use eWOM for Travel Planning and the overall CFA model all shown good-fitting models. This shows that our models have a good model fit (Hair et al., 2010). To further test the goodness of fit measures, Root-Mean-Square Error of Approximation (RMSEA), Incremental Fit Index (IFI), Tucker Lewis Index (TLI), Comparative Fit Index (CFI) and $\chi^{2} / \mathrm{df}$ were used. Based on the accepted thresholds suggested by Hair et al., (2010), Bagozzi and Foxall (1996) and Hu and Bentler (1999), the RMSEA should be below 0.08 . IFI, TLI and CFI should be above 0.90 while $\chi^{2} / \mathrm{df}$ should be between 1 and 2 (Hair et al., 2010). The goodness of fit measures of the above-mentioned measurement models were well within the necessary thresholds. The summary of the model fitness tests can be shown in Table 3. Based on the results in Table 3, the overall model fit was churned with a sample size of 193 . The $\chi^{2}$ p-value and RMSEA were 0.110 and 0.023 indicating that the model fit into the variance-covariance matrix. IFI (0.953), TLI (0.948), CFI (0.950) and $\chi^{2} / \mathrm{df}(1.051)$ were within the thresholds implying that the model had a good fit.

\section{<Table 3: Summary of Results of Goodness of Fit>}

Common Method Variance (CMV) was tested on the dataset using Harman's one-factor test (Podsakoff et al., 2003). The CMV was done via an exploratory factor analysis extracting only one fixed factor. This enabled us to determine the percentage of variance explained by a single factor extracted. Results revealed that the variance 
explained by that single factor was $24.6 \%$ manifested by 57 variables. This result implied that there was no distinct factor and we concluded that CMV was not significant (Hair et al., 2010). Subsequently reliability, convergent and discriminant validity tests were conducted. Prior to these tests, the Cronbach's Alpha, Composite Reliability (CR) and Average Variance Extracted (AVE) values were presented in Table 4.

\section{$<$ Table 4: Summary of results of reliability tests and AVE $>$}

Based on Table 4, Cronbach's Alpha that measures internal consistency in a summated scale was tested on the respective constructs. Results showed that all constructs had Cronbach's Alpha values of 0.7 and above, meeting the threshold of internal consistency (Nunnally, 1978). The CR results also met the threshold of 0.7 and above indicating high-shared variance of indicators with their respective constructs (Hair et al., 2010). As the AVE values of each construct were 5.0 and above, convergent validity was present and met (Said, 2011). Subsequently a discriminant validity test was conducted on each of the constructs using the approach by Fornell and Larcker (1981). In order to achieve discriminant validity, the square root of the AVE of the constructs must be greater than the correlation coefficient $(\phi)$ between the respective constructs. A summary of this validity test is shown in Table 5. For example, the correlation coefficient between Perceived Usefulness of eWOM and Information Adoption was 0.27 while the square roots of AVE of Perceived Usefulness of eWOM and Information Adoption were 0.71 and 0.81 respectively. Since the square roots of AVE of these two constructs were greater than the correlation coefficient, these constructs were considered to have discriminant validity. Based on the results, the highest correlation coefficient amongst the constructs was 0.68 while the lowest square root of AVE was 0.71 . Therefore, we concluded that all constructs showed discriminant validity where the variances in the indicators explained the total variance in their respective constructs (Said, 2011).

\section{$<$ Table 5: Discriminant validity test results >}

The next test involved an examination of the multivariate normality of the data. In this test, the full SEM model using Maximum Likelihood estimation (MLE) was performed. Mardia's coefficient suggested that the data is non-normal and bootstrapping was performed on the full model using 200 bootstrap samples (Arbuckle, 2009; Mardia, 1970). The Bollen-Stine bootstrap p-value was 0.71 indicating that the model has a good fit (Hallak et al., 2012; Arbuckle, 2009). Consequently, the bias corrected estimates as a result of the bootstrapping were compared to the regression weights of the full SEM model. Comparisons showed that the two sets of estimates were consistently similar, p-values of associations were also significant and both sets of standard error estimates were rather similar (see Appendix 1). In short, both bootstrap and full SEM models were relatively similar and suggested that the implied covariance of the dataset was similar to the population covariance (Arbuckle, 2009; Hallak et al., 2012).

\subsection{SEM results and hypotheses testing}

Once the preliminary tests were conducted and results were within acceptable thresholds, SEM was conducted to test the series of hypotheses proposed in the 
literature. The results of the structural model can be mathematically notated. First, let the general equation of the model be as follows.

$$
\eta_{3}=\left(\begin{array}{ccc}
\gamma_{1,1} & \gamma_{1,2} & \gamma_{1,3} \\
0 & 0 & \gamma_{2,3}
\end{array}\right)\left(\begin{array}{l}
\xi_{1} \\
\xi_{2} \\
\xi_{3}
\end{array}\right)+\left(\begin{array}{cc}
0 & 0 \\
\beta_{2,1} & 0 \\
0 & \beta_{3,2}
\end{array}\right)\left(\begin{array}{l}
\eta_{1} \\
\eta_{2}
\end{array}\right)+\zeta \ldots(1)
$$

Where $\gamma$ and $\beta$ are standardized regression weights; $\xi_{1}, \xi_{2}$ and $\xi_{3}$ are eWOM Argument Quality, eWOM Credibility and Perceived Ease of Use of eWOM respectively; $\eta_{1}, \eta_{2}$ and $\eta_{3}$ are Perceived Usefulness of eWOM, Information Adoption and Intention to use eWOM for Travel Planning; and $\zeta$ is the measurement error of $\eta_{3}$. Then, the following equation depicts the overall results of the structural model.

$$
\eta_{3}=\left(\begin{array}{ccc}
0.37 & 0.50 & 0.34 \\
0 & 0 & 0.52
\end{array}\right)\left(\begin{array}{l}
\xi_{1} \\
\xi_{2} \\
\xi_{3}
\end{array}\right)+\left(\begin{array}{cc}
0.42 & 0 \\
0 & 0.89
\end{array}\right)\left(\begin{array}{l}
\eta_{1} \\
\eta_{2}
\end{array}\right) \ldots
$$

$\mathrm{E}(\zeta)=0$ (Anderson and Fornell, 2000)

Based on the results in equation (2), the series of hypotheses were tested at a significance level of 0.05 .

$<$ Figure 2: Overview of the SEM results>

The summary of results is depicted in Table 6. Results revealed that all associations amongst constructs were significant. The mediation stipulated in $\mathrm{H} 1 \mathrm{~b}$ was tested using bootstrapping to assess the extent of mediation of Perceived Usefulness of eWOM on Perceived Ease of Use of eWOM and Information Adoption. Bootstrapping was performed on 2000 bootstrap samples with $95 \%$ bias-corrected confidence intervals. The indirect effect between Perceived Ease of Use of eWOM and Information Adoption was significant at 0.047 while the direct effect was 0.235 (non-significant). This bootstrapping mediation test revealed that Perceived Usefulness of eWOM fully mediates the relationship between Perceived Ease of Use of eWOM and Information Adoption.

\section{<Table 6: SEM results and hypotheses testing>}

Figure 2 also shows the loadings from the second order model to the first order model. The results highlight the measurements that have most influence on the perceived argument quality and credibility of eWOM. Argument strength has the strongest influence on the argument quality of eWOM, followed by confirmation of prior belief, review comprehensiveness, review relevance, review accuracy, review timeliness, review sidedness and review framing. For eWOM credibility, the most important influence is from review consistency, followed by source expertise, source trustworthiness, review rating, and source credibility.

We have also conducted multi-group analyses based on gender and the results is depicted in Table 7. According to the results, there are significant differences between genders when adopting online reviews. The impact of these reviews on the female travel planning decisions is significantly different compared to male travel planning decisions 
as well. Based on the findings, the female gender is more inclined to adopt online reviews when making travel planning decisions than the male gender. Similarly, another multi-group based on the time spent on online reviews was conducted. Results show similar pattern as there is significant difference. However, users are inclined to adopt online information on their travel-planning decisions regardless of the time spent on online reviews. Further findings also revealed that regardless of gender and time spent on online reviews, the perception of users on the argument quality in online reviews is useful.

<Table 7: Multi-group SEM results based on gender >

\section{Discussion and conclusion}

\subsection{Key findings}

This research found that review users will adopt the information in eWOM if they find it useful. This is consistent with previous research (Sussman and Siegal, 2003). This also confirms the application of the TAM and Information Adoption Model in the context of eWOM for travel planning. An important extension to Sussman and Siegal's (2003) model is that our research has incorporated the full TAM model, which includes the perceived ease of use of eWOM, and how perceived ease of use influences information adoption and perceived usefulness of eWOM. Our results also revealed that perceived usefulness of eWOM is able to mediate the relationships of perceived ease of use and the adoption of information. This means that users will find eWOM more useful when they find the application easy to use, and this leads to them being more willing to adopt the information. This is also consistent with previous research results by Ayeh et al., (2013).

Compared with previous research in tourism, our research contributes a more in-depth evaluation in the usefulness of review contents in eWOM for travel planning. This is considered as an important area of eWOM research (Benbasat and Barki, 2007). Our results confirmed the Information Adoption Model which states that a message's information adoption is influenced by both the argument quality and credibility of the message. This study however, has extended previous studies by examining the measurements of eWOM argument quality and credibility. In other words, this study examined the influence of the quality of argument and credibility of eWOM. This extended the research conducted by Cheung et al. (2008). This research model consisted of various factors which influence the adoption of online opinions, but did not measure whether these factors influence the credibility or argument quality of online opinions. By extending Cheung et al. (2008) and Sussman and Siegal's (2003) work, this study demonstrates that argument quality of eWOM is determined by its argument strength, confirmation of prior belief, review comprehensiveness, review relevance, review accuracy, review timeliness, review sidedness and review framing. Our findings also showed that eWOM credibility is determined by its review consistency, source expertise, source trustworthiness, review rating and source credibility.

This study also empirically confirmed the relationship between the adoption of eWOM information and the adoption of eWOM for travel planning. In other words, our results showed that travelers who adopt the information in eWOM will, in turn, use eWOM in 
their travel planning. This confirms the importance of eWOM, and shows that travelers in general will translate their pre-travel decisions (e.g. when going through eWOM reviews) into actual travel planning. Further findings found that gender and time spent on online reviews present different influences on tourists' acceptance of online reviews in travel decision. This is consistent with the findings in other countries implying that both genders have different experiences in terms of occupation, home-related activities, interests and psychological perspectives (Kinnaird and Hall, 1996). The female gender as mentioned earlier are more receptive to online reviews when making travel plans compared to the male gender. Additionally, the variance-covariance matrix from female gender fits into the model better than the male gender (See Table 7). Both genders concur that perceived ease of use of the website's credibility of the eWOM are likely to make them adopt online information when making travel plans. Further findings also found that the intention to use eWOM for travel planning does not depend on the duration of time spent on online reviews. However, the more time users spend on online reviews, the more likely they will adopt the information for travel decision. Online users will also find that the more they spend on online reviews, the more likely they will find the reviews useful especially when the reviews are credible.

\subsection{Theoretical implications}

This research extended existing eWOM and information system adoption studies and focused on the travel planning context. E-commerce has a major impact on the travel industry and has transformed the travel industry's business models and landscape. Therefore, with the emergence of eWOM, it is important to examine eWOM adoption in the context of travel planning. This research validated the significant roles of eWOM argument quality and credibility in predicting the information usefulness of eWOM. Furthermore, we also validated the significant influence of eWOM information usefulness and ease of use on the adoption of eWOM, and the significant relationships between eWOM information adoption and users' intentions to use eWOM to plan their travels. This research has developed a conceptual model which has been developed from previous theories such as TAM, ELM and information adoption model. As our results showed, all relationships developed in our model are significant. Therefore, this study presented a model that can explain users' decisions in using eWOM in planning their travel.

This research also developed second order measurement constructs of eWOM argument quality and credibility. Although the information adoption model developed by Sussman and Siegal (2003) validated the importance of a message's argument quality and credibility in predicting information usefulness, there is still more research required to know what affects the argument quality and credibility of a message; especially on how age and time spent on online reviews affect users' decisions in using eWOM in planning their travel. This research has therefore extended previous information adoption research by developing and validating the eWOM argument quality and credibility measurements in the context of eWOM in travel planning. Therefore, beyond showing that argument quality and credibility affects information adoption in the context of eWOM, this study identifies the specific aspects of argument quality (e.g. argument strength, confirmation of prior belief, etc.) and credibility (e.g. source expertise, review consistency, etc.) that can be influential on an eWOM's perceived usefulness. 
Previous research has not paid a great deal of attention to examining the linkage between travelers' intentions to adopt eWOM and their intentions to use eWOM for their travel planning (Cheung and Thadani, 2012). This research also presented how the dimensions of gender and time spent on online reviews affect online users' intentions to use eWOM for travel planning. Most research models in the extant literature use either one of the factors as a dependent variable and did not address categorical dimensions which present more robust findings to the extant literature. This research developed a conceptual model that confirms the relationships between the adoption of eWOM information and the intention to use eWOM for travel planning as a result of the information adoption.

Lastly, prior literature from TAM suggests that perceived usefulness can mediate the perceived ease of use of an information system. Our results confirmed this hypothesis and shows that eWOM which is easy to use will be perceived to be more useful to users, and this will in turn result in the use of eWOM for travel planning.

\subsection{Practical implications}

Understanding why travelers adopt eWOM information in their travel planning is important for the survival and growth of travel eWOM. There are many new travel eWOM portals that are being developed and introduced, and our study showed that credibility and argument quality of eWOM will enhance the adoption of eWOM in travel planning, and potentially will also attract repeat visits to eWOM portals. Results from our study confirmed that perceived ease of use and perceived usefulness of eWOM information will influence the adoption of eWOM information. Additionally, gender and time spent on online reviews provide new insights to operators and administrators in their communication strategies. These findings are consistent with previous studies. Therefore, operators and administrators of eWOM can use the findings from this study to focus on how to improve the argument quality and source credibility of eWOM. For example, in order to improve the quality of argument in eWOM, review site administrators can provide guidelines to users on what are considered to be relevant, accurate, valid and convincing arguments. Administrators can also provide some templates or examples of good reviews such as what could be covered in these reviews (e.g. cost of travel, cleanliness of travel location, etc.). These administrators also need to ensure that reviews are updated frequently.

In order to further improve the credibility of the reviews, an eWOM portal can also consider rewarding contributors who have high knowledge of the travel topic as well as those who consistently received high ratings for their reviews. This is because travelers view reviews posted by those with high expertise to be more credible. Similar to e-review sites such as Taobao, administrators can also ensure that in eWOM designs, travelers are able to rate the reviewer or that a reviewer gets an average score for reviews he or she has completed. By doing so, whenever travelers read a review, they will have a clearer idea of whether the reviewer is credible or trustworthy (e.g. based on their average score given by other travelers) (Chong and Ngai, 2013).

Although practitioners will not be able to and should not amend the reviews on eWOM portals, they can improve the usability of eWOM by ensuring that their systems present information effectively to travelers. For example, the system could allow travelers to 
rate a review's argument strength, consistency, relevance, confirmation with their prior belief and so forth. Therefore, the eWOM will not give a general evaluation score of the overall reviews, but instead, provide ratings for different dimensions of the eWOM reviews. As shown in our findings, all these factors will influence the argument quality and credibility of eWOM. By allowing different ratings on the dimensions of argument quality and credibility, travelers will be able to form their own judgment based on which aspects of the review are most important to them.

Our results also confirmed the importance of eWOM ease of use. As such, eWOM portal designers should consider ensuring that the system is well-designed and userfriendly. The developers of eWOM could also consider presenting summary information that is easy to understand. For example, graphical displays of the ratings (e.g. bar graph) or summarized views can help ensure the information is easy to understand by the users.

Lastly, given that our study confirms the linkage between eWOM information adoption and using eWOM in travel planning, eWOM developers could consider linking travel products and services in their system. For example, in positive eWOM reviews of a particular hotel or place of interest, the system can perhaps display a link where travelers can book or purchase the product or service, which may help convert the eWOM's marketing and promotional efforts into sales.

\subsection{Limitations and Future Research}

There are several limitations to this study. Firstly, the sample for this research is small although it meets the minimum recommendations by Hair et al. (2010). Future studies should consider collecting additional data to further validate this research model. Secondly, this research is also based on respondents from China, and therefore, further studies are needed to examine if the results can be generalized for other countries. Future studies could also consider if there are cultural differences in travelers' perceptions of eWOM credibility and argument quality. Lastly, our study was not able to incorporate all factors which may be relevant to this study and so further theoretical development may be necessary to develop the conceptual model.

\section{Acknowledgement}

This study was financially supported by the National Natural Science Foundation of

China (NSFC) [NSFC grant no. 71402076], International Doctoral Innovation Centre,

Ningbo Education Bureau and the University of Nottingham.

\section{References:}

Anderson, E. and Fornell, C. (2000), "Foundations of the American Customer Satisfaction Index", Total Quality Management, Vol. 11 No. 7, pp. 869-882.

Anderson, J. and Gerbing, D. (1988), "Structural equation modeling in practice: A review and recommended two-step approach", Psychological Bulletin, Vol. 103 No. 3, pp. 411-423. 
Arbuckle, J., (2009). Amos 18 user's guide. SPSS Incorporated, Armonk, USA.

Ayeh, J., Au, N. and Law, R. (2013), "Predicting the intention to use consumergenerated media for travel planning", Tourism Management, Vol. 35, pp. 132143.

Bagozzi, R. and Foxall, G. (1996), "Construct validation of a measure of adaptiveinnovative cognitive styles in consumption", International Journal of Research in Marketing, Vol. 13 No. 3, pp. 201-213.

Belch, G. (1981), "An Examination of Comparative and Noncomparative Television Commercials: The Effects of Claim Variation and Repetition on Cognitive Response and Message Acceptance", Journal of Marketing Research, Vol. 18 No. 3, pp. 333-349.

Benbasat, I. and Barki, H., (2007), "Quo vadis TAM?", Journal of the association for information systems, Vol. 8 No. 4, p. 7.

Bhattacherjee, A. and Sanford, C. (2006), "Influence Processes for Information Technology Acceptance: An Elaboration Likelihood Model”, MIS Quarterly, Vol. 30 No. 4, p. 805.

Capriello, A., Mason, P., Davis, B. and Crotts, J. (2013), "Farm tourism experiences in travel reviews: A cross-comparison of three alternative methods for data analysis", Journal of Business Research, Vol. 66 No. 6, pp. 778-785.

Casaló, L., Flavián, C. and Guinalíu, M. (2010), "Determinants of the intention to participate in firm-hosted online travel communities and effects on consumer behavioral intentions", Tourism Management, Vol. 31 No. 6, pp. 898-911.

Chan, Y. and Ngai, E. (2011), "Conceptualising electronic word of mouth activity", Marketing Intelligence and Planning, Vol. 29 No. 5, pp. 488-516.

Cheung, C.M.Y., Sia, C.L. and Kuan, K.K., (2012), "Is this review believable? A study of factors affecting the credibility of online consumer reviews from an ELM perspective", Journal of the Association for Information Systems, Vol. 13 No. 8, p. 618.

Cheung, C., Lee, M. and Rabjohn, N. (2008), "The impact of electronic word-ofmouth", Internet Research, Vol. 18 No. 3, pp. 229-247.

Cheung, C. and Thadani, D. (2012), "The impact of electronic word-of-mouth communication: A literature analysis and integrative model", Decision Support Systems, Vol. 54 No. 1, pp. 461-470.

Cheung, M., Luo, C., Sia, C. and Chen, H. (2009), "Credibility of Electronic Word-ofMouth: Informational and Normative Determinants of On-line Consumer Recommendations", International Journal of Electronic Commerce, Vol. 13 No. 4, pp. 9-38.

Chong, A., Chan, F. and Ooi, K. (2012), "Predicting consumer decisions to adopt mobile commerce: Cross country empirical examination between China and Malaysia”, Decision Support Systems, Vol. 53 No. 1, pp. 34-43.

Chong, A. and Ngai, E. (2013), "What Influences Travellers' Adoption of a Locationbased Social Media Service for Their Travel Planning?", paper presented at PACIS 2013 Proceedings, 18 June-22 June, Jeju Island, Korea, available at: https://aisel.aisnet.org/pacis2013/210 (accessed 29 December 2017).

Davis, F. (1989), "Perceived Usefulness, Perceived Ease of Use, and User Acceptance of Information Technology", MIS Quarterly, Vol. 13 No. 3, pp. 319-340.

Fornell, C. and Larcker, D. (1981), "Evaluating Structural Equation Models with Unobservable Variables and Measurement Error", Journal of Marketing Research, Vol. 18 No. 1, pp. 39-50. 
Gefen, D., Karahanna, E. and Straub, D.W., (2003), "Trust and TAM in online shopping: an integrated model", MIS quarterly, Vol. 27 No. 1, pp. 51-90.

Gretzel, U. and Yoo, K.H. (2008), "Use and Impact of Online Travel Reviews", in Information and Communication Technologies in Tourism 2008 in Innsbruck, Vienna, 2008, Springer Vienna, Vienna, pp. 35-46.

Grewal, R., Cline, T. W., and Davies, A. (2003), "Early-entrant advantages, word of mouth communication, brand similarity, and the consumer's decision-making process", Journal of Consumer Psychology, Vol. 13 No. 3, pp. 187-197.

Gvili, Y. and Levy, S. (2016), "Antecedents of attitudes toward eWOM communication: differences across channels", Internet Research, Vol. 26 No. 5, pp. 1030-1051.

Hair Junior, J. (2010), Multivariate data analysis with readings, Prentice Hall, New Jersey, USA.

Hallak, R., Brown, G. and Lindsay, N. (2012), "The Place Identity - Performance relationship among tourism entrepreneurs: A structural equation modelling analysis", Tourism Management, Vol. 33 No. 1, pp. 143-154.

Hennig-Thurau, T., Gwinner, K., Walsh, G. and Gremler, D. (2004), "Electronic wordof-mouth via consumer-opinion platforms: What motivates consumers to articulate themselves on the Internet?", Journal of Interactive Marketing, Vol. 18 No. 1, pp. 38-52.

Hu, L. and Bentler, P. (1999), "Cutoff criteria for fit indexes in covariance structure analysis: Conventional criteria versus new alternatives", Structural Equation Modeling: A Multidisciplinary Journal, Vol. 6 No. 1, pp. 1-55.

Kinnaird, V. and Hall, D. (1996), "Understanding tourism processes: A gender-aware framework", Tourism Management, Vol. 17 No. 2, pp. 95-102.

Klein, L.R., (1998), "Evaluating the potential of interactive media through a new lens: Search versus experience goods", Journal of business research, Vol. 41 No. 3, pp. 195-203.

Kwon, J., Han, I. and Kim, B. (2017), "Effects of source influence and peer referrals on information diffusion in Twitter", Industrial Management \& Data Systems, Vol. 117 No. 5, pp. 896-909.

Lee, I. (2017), "A study of the effect of social shopping deals on online reviews", Industrial Management \& Data Systems, Vol. 117 No. 10, pp. 2227-2240.

Lin, H.F. (2007), "Predicting consumer intentions to shop online: An empirical test of competing theories", Electronic Commerce Research and Applications, Vol. 6 No. 4, pp. 433-442.

Lin, C.A. and Xu, X. (2017), "Effectiveness of online consumer reviews", Internet Research, Vol. 27 No. 2, pp. 362-380.

Litvin, S., Goldsmith, R. and Pan, B. (2008), "Electronic word-of-mouth in hospitality and tourism management", Tourism Management, Vol. 29 No. 3, pp. 458-468.

Lu, X., Ba, S., Huang, L. and Feng, Y. (2013), "Promotional Marketing or Word-ofMouth? Evidence from Online Restaurant Reviews", Information Systems Research, Vol. 24 No. 3, pp. 596-612.

Mardia, K. (1970), "Measures of Multivariate Skewness and Kurtosis with Applications", Biometrika, Vol. 57 No. 3, p. 519.

Mayer, K.J. and Sparrowe, R.T. (2013), "Integrating theories in AMJ articles", Academy of Management Journal, Vol. 56 No. 4, pp. 917-922.

McKinney, V., Yoon, K. and Zahedi, F. "Mariam". (2002), "The Measurement of WebCustomer Satisfaction: An Expectation and Disconfirmation Approach", Information Systems Research, Vol. 13 No. 3, pp. 296-315. 
Muk, A. and Chung, C. (2015), "Applying the technology acceptance model in a twocountry study of SMS advertising", Journal of Business Research, Vol. 68 No. 1, pp. 1-6.

Nunnally, J. (1978), Psychometric theory, McGraw-Hill, New York, USA.

Oh, H., Jeong, M. and Baloglu, S. (2013), "Tourists' adoption of self-service technologies at resort hotels", Journal of Business Research, Vol. 66 No. 6, pp. 692-699.

Owusu, R.A., Mutshinda, C.M., Antai, I., Dadzie, K.Q. and Winston, E.M. (2016), "Which UGC features drive web purchase intent? A spike-and-slab Bayesian Variable Selection Approach", Internet Research, Vol. 26 No. 1, pp. 22-37.

Papathanassis, A. and Knolle, F. (2011), "Exploring the adoption and processing of online holiday reviews: A grounded theory approach", Tourism Management, Vol. 32 No. 2, pp. 215-224.

Petty, R.E. and Cacioppo, J.T. (1986), "The Elaboration Likelihood Model of Persuasion", Advances in Experimental Social Psychology, Vol. 19, pp. 123205.

Petty, R., Cacioppo, J. and Schumann, D. (1983), "Central and Peripheral Routes to Advertising Effectiveness: The Moderating Role of Involvement", Journal of Consumer Research, Vol. 10 No. 2, pp. 135-146.

Petty, R. and Wegener, D. (1998), "Matching Versus Mismatching Attitude Functions: Implications for Scrutiny of Persuasive Messages', Personality and Social Psychology Bulletin, Vol. 24 No. 3, pp. 227-240.

Podsakoff, P., MacKenzie, S., Lee, J. and Podsakoff, N. (2003), "Common method biases in behavioral research: A critical review of the literature and recommended remedies', Journal of Applied Psychology, Vol. 88 No. 5, pp. 879-903.

Richins, M.L., (1983), "Negative word-of-mouth by dissatisfied consumers: A pilot study", Journal of Marketing, Vol. 47 No. 1, pp. 68-78.

Said, H., Badru, B.B., and Shahid, M. (2011), "Confirmatory Factor Analysis (CFA) for Testing Validity and Reliability Instrument in the Study of Education", Australian Journal of Basic and Applied Sciences, Vol. 5 No. 12, pp. 1098-1193.

Sher, P. and Lee, S. (2009), "Consumer skepticism and online reviews: An Elaboration Likelihood Model perspective", Social Behavior and Personality: an international journal, Vol. 37 No. 1, pp. 137-143.

Soderlund, M., and Rosengren, S. (2007), "Receiving word-of-mouth from the service customer: An emotion-based effectiveness assessment', Journal of Retailing and Consumer Services, Vol. 14 No. 2, pp. 123-136.

Sussman, S. and Siegal, W. (2003), "Informational Influence in Organizations: An Integrated Approach to Knowledge Adoption', Information Systems Research, Vol. 14 No. 1, pp.47-65.

Teo, T., Lee, C. and Chai, C. (2007), "Understanding pre-service teachers' computer attitudes: applying and extending the technology acceptance model", Journal of Computer Assisted Learning, Vol. 24 No. 2, pp. 128-143.

Tormala, Z. and Petty, R. (2004), "Source Credibility and Attitude Certainty: A Metacognitive Analysis of Resistance to Persuasion", Journal of Consumer Psychology, Vol. 14 No. 4, pp. 427-442.

Tsao, W.C., Hsieh, M.T., Shih, L.W. and Lin, T.M., (2015), "Compliance with eWOM: The influence of hotel reviews on booking intention from the perspective of consumer conformity', International Journal of Hospitality Management, Vol. 46, pp. 99-111. 
Vallespín, M., Molinillo, S. and Muñoz-Leiva, F. (2017), "Segmentation and explanation of smartphone use for travel planning based on socio-demographic and behavioral variables", Industrial Management \& Data Systems, Vol. 117 No. 3, pp. 605-619.

Venkatesh, V. and Speier, C. (1999), "Computer Technology Training in the Workplace: A Longitudinal Investigation of the Effect of Mood", Organizational Behavior and Human Decision Processes, Vol. 79 No. 1, pp. 128.

Venkatesh, V. and Bala, H. (2008), "Technology Acceptance Model 3 and a Research Agenda on Interventions", Decision Sciences, Vol. 39 No. 2, pp. 273-315.

Venkatesh, V., Morris, M.G., Davis, G.B. and Davis, F.D. (2003), "User Acceptance of Information Technology: Toward a Unified View", MIS Quarterly, Vol. 27 No. 3, p. 425.

Venkatesh, V., Thong, J.Y. and Xu, X., (2012), "Consumer acceptance and use of information technology: extending the unified theory of acceptance and use of technology", MIS quarterly, Vol. 36 No. 1, pp. 157-178.

Vermeulen, I. and Seegers, D. (2009), "Tried and tested: The impact of online hotel reviews on consumer consideration", Tourism Management, Vol. 30 No. 1, pp. 123-127.

Xie, G. and Boush, D. (2011), "How susceptible are consumers to deceptive advertising claims? A retrospective look at the experimental research literature", The Marketing Review, Vol. 11 No. 3, pp. 293-314.

Yang, J., Mai, E. and Ben-Ur, J. (2012), "Did you tell me the truth? The influence of online community on eWOM", International Journal of Market Research, Vol. 54 No. 3, pp. 369-389.

Yang, X., Pan, B., Evans, J.A. and Lv, B. (2015), "Forecasting Chinese tourist volume with search engine data", Tourism Management, Vol. 46, pp. 386-397.

Yap, B. and Khong, K.W. (2006), "Examining the effects of customer service management (CSM) on perceived business performance via structural equation modelling", Applied Stochastic Models in Business and Industry, Vol. 22 No. 5, pp. 587-605.

Zhang, K.Z.K., Zhao, S.J., Cheung, C.M.K. and Lee, M.K.O. (2014), "Examining the influence of online reviews on consumers' decision-making: A heuristicsystematic model", Decision Support Systems, Vol. 67, pp. 78-89.

Zhou, T. (2017), "Understanding location-based services users' privacy concern", Internet Research, Vol. 27 No. 3, pp. 506-519.

Zhou, X., Song, Q., Li, Y., Tan, H. and Zhou, H. (2017), "Examining the influence of online retailers' micro-blogs on consumers' purchase intention", Internet Research, Vol. 27 No. 4, pp. 819-838. 


\section{Appendix 1 - Comparison of bias corrected estimates and regression weights}

\begin{tabular}{|l|c|c|c|c|c|c|c|c|}
\hline & $\begin{array}{c}\text { Bias Corrected } \\
\text { Estimates }\end{array}$ & Lower & Upper & S.E. & $\begin{array}{c}\text { p- } \\
\text { value }\end{array}$ & $\begin{array}{c}\text { Regression } \\
\text { Weights }\end{array}$ & $\begin{array}{c}\text { S.E. } \\
\text { value }\end{array}$ \\
\hline $\begin{array}{l}\text { eWOM Argument } \\
\text { Quality } \rightarrow \text { Perceived Usefulness } \\
\text { of eWOM }\end{array}$ & 0.242 & 0.128 & 0.429 & 0.099 & 0.001 & 0.229 & 0.086 & 0.015 \\
\hline $\begin{array}{l}\text { Perceived Ease of Use of eWOM } \\
\text { PPerceived Usefulness of } \\
\text { eWOM }\end{array}$ & 0.215 & 0.025 & 0.395 & 0.096 & 0.050 & 0.244 & 0.116 & 0.025 \\
\hline $\begin{array}{l}\text { eWOM Credibility } \rightarrow \text { Perceived } \\
\text { Usefulness of eWOM }\end{array}$ & 0.372 & 0.196 & 0.658 & 0.140 & 0.001 & 0.361 & 0.132 & 0.008 \\
\hline $\begin{array}{l}\text { Perceived Usefulness of eWOM } \\
\rightarrow \text { Information Adoption }\end{array}$ & 0.480 & 0.179 & 1.783 & 0.193 & 0.002 & 0.580 & 0.174 & 0.013 \\
\hline $\begin{array}{l}\text { Perceived Ease of Use of eWOM } \\
\text { Information Adoption }\end{array}$ & 0.377 & -0.195 & 0.628 & 0.118 & 0.019 & 0.274 & 0.315 & 0.001 \\
\hline $\begin{array}{l}\text { Information Adoption } \\
\text { Intention to use eWOM for } \\
\text { Travel Planning }\end{array}$ & 0.915 & 0.713 & 1.217 & 0.209 & 0.001 & 0.928 & 0.153 & 0.001 \\
\hline
\end{tabular}

Note: S.E. denotes Standard Error 
Figure 1 Research Model

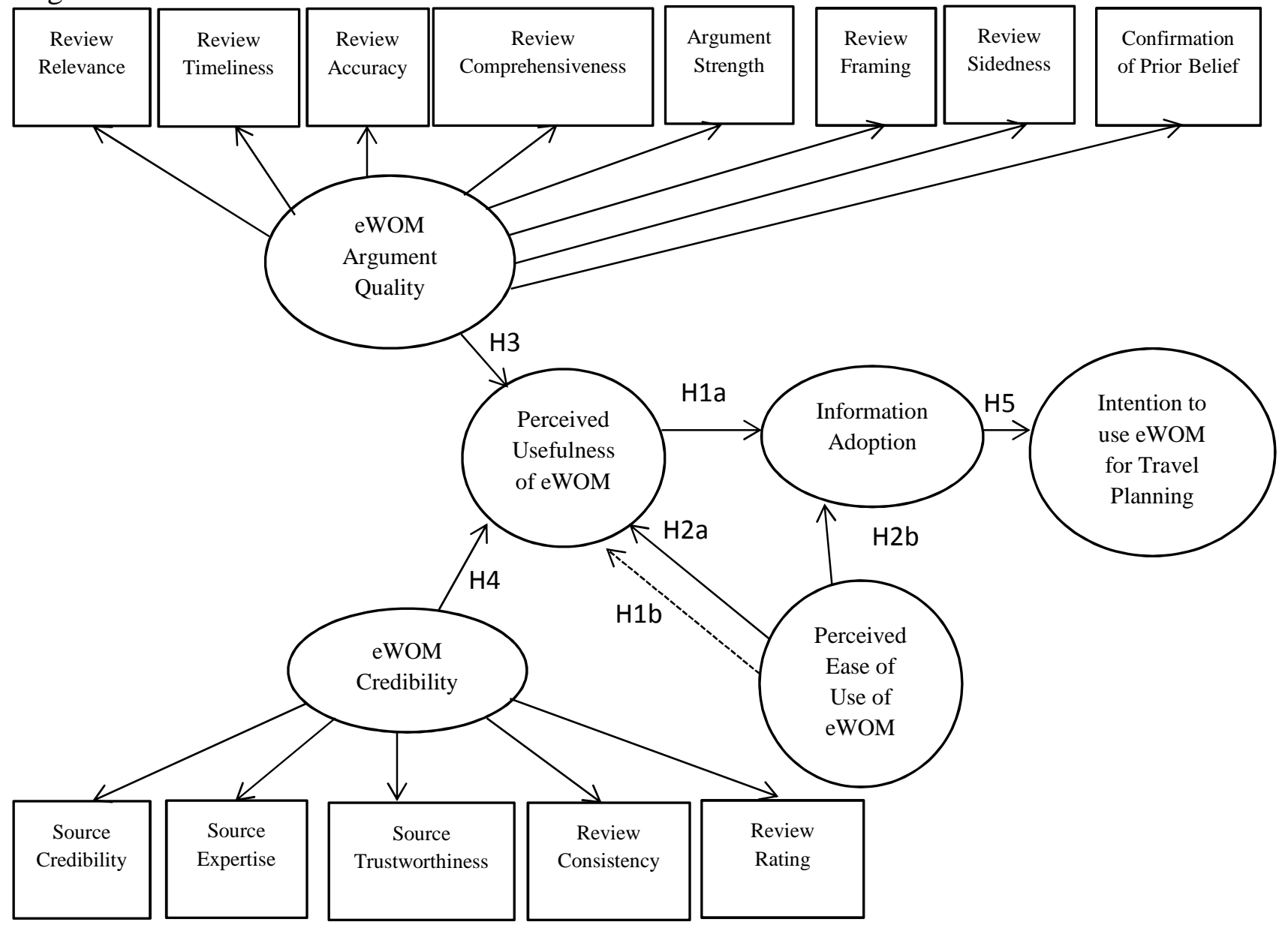

Note: dotted line denotes mediating relationship 
Figure 2: Overview of the SEM results

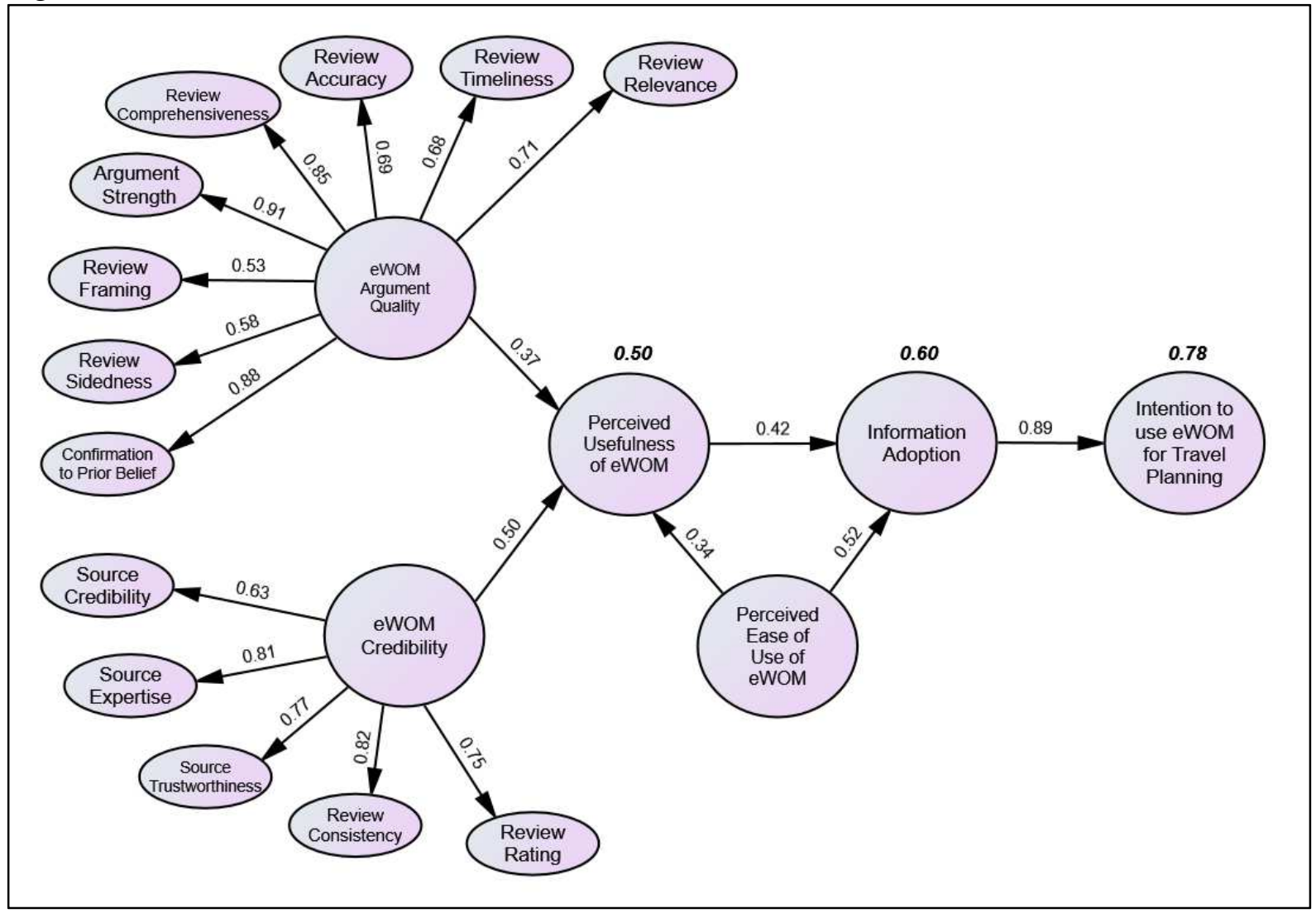

Note: Values in bold italic (next to the constructs) denotes $\mathrm{R}^{2}$

Values oblique to the paths denotes standardized regression weights 
Table 1: List of items and measurement models

\begin{tabular}{|c|c|c|}
\hline $\begin{array}{l}\text { Second order } \\
\text { measurement } \\
\text { models }\end{array}$ & $\begin{array}{l}\text { First order } \\
\text { measurement models }\end{array}$ & Items \\
\hline \multirow{8}{*}{$\begin{array}{l}\text { eWOM } \\
\text { Argument } \\
\text { Quality }\end{array}$} & Review Relevance & $\begin{array}{l}\text { I think the reviewers of the comments in this } \\
\text { website gave relevant reviews. } \\
\text { I I think the reviewers of the comments in this } \\
\text { website are informative. } \\
\text { I I think the reviewers of the comments in this } \\
\text { website are helpful. }\end{array}$ \\
\hline & Review Timeliness & $\begin{array}{ll} & \text { The comments in this website are current. } \\
\text { - } & \text { The comments in this website are timely. }\end{array}$ \\
\hline & Review Accuracy & $\begin{array}{l}\text { - The comments in this website are accurate. } \\
\text { - The comments in this website are correct. } \\
\text { - The comments in this website are reliable. }\end{array}$ \\
\hline & $\begin{array}{l}\text { Review } \\
\text { Comprehensiveness }\end{array}$ & $\begin{array}{l}\text { - The comments in this website sufficiently } \\
\text { complete my needs. } \\
\text { The comments in this website have sufficient } \\
\text { breadth and depth. }\end{array}$ \\
\hline & Argument Strength & $\begin{array}{l}\text { - The comments in this website are convincing. } \\
\text { - The comments in this website are strong. } \\
\text { - The comments in this website are persuasive. } \\
\text { - The comments in this website are good. }\end{array}$ \\
\hline & Review Framing & $\begin{array}{l}\text { The comments in this website stress positive } \\
\text { implication of discussed goods and services. } \\
\text { favorable appraisal of discussed goods and services. } \\
\text { - Overall, the comments in this website stress } \\
\text { favorable appraisal of discussed goods and services. }\end{array}$ \\
\hline & Review Sidedness & $\begin{array}{l}\text { The comments in this website include both pros } \\
\text { and cons of targeted goods and services. } \\
\text { The comments in this website include only one- } \\
\text { sided opinion (positive or negative). } \\
\text { - The comments in this website seems bias toward } \\
\text { one side (positive or negative). }\end{array}$ \\
\hline & $\begin{array}{l}\text { Confirmation with } \\
\text { Prior Belief }\end{array}$ & $\begin{array}{l}\text { - The information from review contradicted the } \\
\text { knowledge you had before reading it. } \\
\text { - The comments in this website support your } \\
\text { impression of your targeted goods and services. } \\
\text { The comments in this website reinforced } \\
\text { information you had previously known about the } \\
\text { targeted traveling goods and services. }\end{array}$ \\
\hline \multirow[t]{2}{*}{$\begin{array}{l}\text { eWOM } \\
\text { Credibility }\end{array}$} & Source Credibility & $\begin{array}{l}\text { - Based on the comment rating, I think the } \\
\text { reviewers of the comments in this website are } \\
\text { reputable. } \\
\text { - Based on the comment rating, I think the } \\
\text { reviewers of the comments in this website are highly } \\
\text { rated by other sites' participants. } \\
\text { - Based on the comments rating, I think the } \\
\text { reviewers of the comments in this website are good. }\end{array}$ \\
\hline & Source Expertise & $\begin{array}{l}\text { I think the reviewers of the comments in this } \\
\text { website are knowledgeable in evaluating quality of } \\
\text { traveling goods and services. }\end{array}$ \\
\hline
\end{tabular}




\begin{tabular}{|c|c|}
\hline & $\begin{array}{l}\text { - I think the reviewers of the comments in this } \\
\text { website are experts in evaluating quality of traveling } \\
\text { goods and services. }\end{array}$ \\
\hline $\begin{array}{l}\text { Source } \\
\text { Trustworthiness }\end{array}$ & $\begin{array}{l}\text { - I think the reviewers of the comments in this } \\
\text { website are trustworthy. } \\
\text { Based on the comments rating, I think the } \\
\text { reviewers of the comments in this website are } \\
\text { trustworthy. }\end{array}$ \\
\hline $\begin{array}{l}\text { Review } \\
\text { Consistency }\end{array}$ & $\begin{array}{l}\text { Comments in the review are consistent with } \\
\text { other reviews. } \\
\text { - Comments in the review are similar to other } \\
\text { reviews. } \\
\text { - Comments in the review are not much different } \\
\text { with other reviews. }\end{array}$ \\
\hline Review Rating & $\begin{array}{l}\text { Based on review rating, review was found to be } \\
\text { favorable by other audiences. } \\
\text { Based on review rating, review is highly rated } \\
\text { by other audiences. } \\
\text { - Based on review rating, review is considered } \\
\text { good by other audiences. }\end{array}$ \\
\hline $\begin{array}{l}\text { Perceived Ease of } \\
\text { Use of eWOM }\end{array}$ & $\begin{array}{l}\text { It is easy to use this website. } \\
\text { - } \quad \text { I know how to use this website. } \\
\quad \text { I am able to use this website for the required } \\
\text { services/activities easily. }\end{array}$ \\
\hline $\begin{array}{l}\text { Perceived } \\
\text { Usefulness of } \\
\text { eWOM }\end{array}$ & $\begin{array}{l}\text { - The comments on this website are relevant to } \\
\text { my traveling purchasing decision. } \\
\text { - The comments on this website are appropriate to } \\
\text { my traveling purchasing decision. } \\
\text { - The comments on this website are applicable to } \\
\text { my traveling purchasing decision. }\end{array}$ \\
\hline $\begin{array}{l}\text { Information } \\
\text { Adoption }\end{array}$ & $\begin{array}{l}\text { - I will closely follow the suggestions of the } \\
\text { positive evaluation and purchase for the targeted } \\
\text { traveling goods and services. } \\
\text { - I agree with the suggestions/comments in this } \\
\text { website. } \\
\text { k Information from this website contributed to my } \\
\text { knowledge of discussed holiday/travel product/service. }\end{array}$ \\
\hline $\begin{array}{l}\text { Intention to use } \\
\text { eWOM for Travel } \\
\text { Planning }\end{array}$ & $\begin{array}{l}\text { - This website made it easier for me to make } \\
\text { holiday/travel purchase decision. (e.g., purchase or not } \\
\text { purchase). } \\
\text { - This website has enhanced my effectiveness in } \\
\text { making holiday/travel purchase decision. } \\
\text { - This website motivated me to make } \\
\text { travel/holiday purchase actions. }\end{array}$ \\
\hline
\end{tabular}

Note: items were adopted from Ayeh et al., 2013; Cheung et al., 2009; Davis, 1989; Cheung et al., 2008 
Table 2 Profile of Respondents

\begin{tabular}{llrr}
\hline Demographic Profile & & Frequency & Percentage \\
\hline Gender & Male & 57 & $29.53 \%$ \\
& Female & 136 & $70.47 \%$ \\
& $21-30$ & 84 & $43.52 \%$ \\
Age & $31-40$ & 101 & $52.33 \%$ \\
& $41-50$ & 3 & $1.55 \%$ \\
& Above 50 & 5 & $2.59 \%$ \\
& High School & 35 & $18.13 \%$ \\
Education & Diploma & 6 & $3.11 \%$ \\
& Bachelor Degree & 146 & $75.65 \%$ \\
& Graduate Degree & 6 & $3.11 \%$ \\
& & & \\
& Less than 2 hours & 92 & $47.67 \%$ \\
How much time do you spend on & 75 & $38.86 \%$ \\
eWOM for each of your travel trip & $2-5$ hours & 19 & $9.84 \%$ \\
planning? & $5-10$ hours & & \\
& More than 10 & 7 & $3.63 \%$ \\
\hline
\end{tabular}


Table 3: Summary of Results of Goodness of Fit

\begin{tabular}{|c|c|c|c|c|c|c|c|c|c|}
\hline $\begin{array}{l}\text { First order } \\
\text { measurement models }\end{array}$ & $\begin{array}{l}\text { Second } \\
\text { order } \\
\text { factors }\end{array}$ & $\chi^{2}$ & $\mathrm{df}$ & $\begin{array}{l}\mathrm{p} \text {-value } \\
(\mathrm{p}>0.05)\end{array}$ & $\begin{array}{c}\text { RMSEA } \\
(<0.08)\end{array}$ & $\begin{array}{c}\text { IFI } \\
(>0.90)\end{array}$ & $\begin{array}{c}\text { TLI } \\
(>0.90)\end{array}$ & $\begin{array}{c}\text { CFI } \\
(>0.90)\end{array}$ & $\begin{array}{c}\chi^{2} / \mathrm{df} \\
(1< \\
\chi^{2} / \mathrm{df} \\
<2)\end{array}$ \\
\hline $\begin{array}{l}\text { - Review Relevance } \\
\text { - Review Timeliness } \\
\text { - Review Accuracy } \\
\text { - Review } \\
\text { Comprehensiveness } \\
\text { - Argument Strength } \\
\text { - Review Framing } \\
\text { - Review Sidedness } \\
\text { - Confirmation with } \\
\text { Prior Belief }\end{array}$ & $\begin{array}{l}\text { eWOM } \\
\text { Argument } \\
\text { Quality }\end{array}$ & 236.9 & 225 & $0.280 *$ & 0.028 & 0.971 & 0.965 & 0.968 & 1.053 \\
\hline $\begin{array}{l}\text { - Source Credibility } \\
\text { - Source Expertise } \\
\text { - Source } \\
\text { Trustworthiness } \\
\text { - Review } \\
\text { Consistency } \\
\text { - Review Rating }\end{array}$ & $\begin{array}{c}\text { eWOM } \\
\text { Credibility }\end{array}$ & 81.4 & 73 & $0.234 *$ & 0.041 & 0.956 & 0.940 & 0.952 & 1.115 \\
\hline $\begin{array}{l}\text { Perceived Ease of } \\
\text { Use of eWOM }\end{array}$ & & 3.031 & 2 & $0.220 *$ & 0.030 & 0.978 & 0.927 & 0.976 & 1.515 \\
\hline $\begin{array}{l}\text { Perceived Usefulness } \\
\text { of eWOM }\end{array}$ & & 1.126 & 1 & $0.289 *$ & 0.026 & 0.999 & 0.997 & 0.999 & 1.126 \\
\hline $\begin{array}{l}\text { Information } \\
\text { Adoption }\end{array}$ & - & 3.9 & 2 & $0.143^{*}$ & 0.066 & 0.970 & 0.955 & 0.970 & 1.943 \\
\hline $\begin{array}{l}\text { Intention to use } \\
\text { eWOM for Travel } \\
\text { Planning }\end{array}$ & & 1.532 & 1 & $0.216^{*}$ & 0.018 & 0.973 & 0.910 & 0.970 & 1.532 \\
\hline Overall CFA & & 1213.7 & 1152 & $0.138 *$ & 0.025 & 0.929 & 0.918 & 0.922 & 1.045 \\
\hline Overall SEM & & 1221.5 & 1162 & $0.110^{*}$ & 0.023 & 0.953 & 0.948 & 0.950 & 1.051 \\
\hline
\end{tabular}

Note: $*$ denotes non-significant at 0.05 
Table 4: Summary of results of reliability tests and AVE

\begin{tabular}{|c|c|c|c|c|c|}
\hline Constructs & Indicators & $\lambda$ & $\begin{array}{c}\text { Cronbach's } \\
\text { Alpha }\end{array}$ & $\begin{array}{l}\text { Composite } \\
\text { Reliability }\end{array}$ & $\begin{array}{l}\text { Average } \\
\text { Variance } \\
\text { Extracted } \\
\text { (AVE) }\end{array}$ \\
\hline $\begin{array}{l}\text { eWOM } \\
\text { Argument } \\
\text { Quality }\end{array}$ & $\begin{array}{l}\text { - Review Relevance } \\
\text { - Review Timeliness } \\
\text { - Review Accuracy } \\
\text { - Review } \\
\text { Comprehensiveness } \\
\text { - Argument Strength } \\
\text { - Review Framing } \\
\text { - Review Sidedness } \\
\text { - Confirmation of Prior } \\
\text { Belief } \\
\end{array}$ & $\begin{array}{l}0.57 \\
0.65 \\
0.65 \\
\\
0.84 \\
0.89 \\
0.63 \\
0.66 \\
0.74\end{array}$ & 0.878 & 0.89 & 0.50 \\
\hline $\begin{array}{l}\text { eWOM } \\
\text { Credibility }\end{array}$ & $\begin{array}{l}\text { - Source Credibility } \\
\text { - Source Expertise } \\
\text { - Source } \\
\text { Trustworthiness } \\
\text { - Review Consistency } \\
\text { - Review Rating } \\
\end{array}$ & $\begin{array}{l}0.83 \\
0.77 \\
0.76 \\
\\
0.70 \\
0.81 \\
\end{array}$ & 0.826 & 0.88 & 0.60 \\
\hline $\begin{array}{l}\text { Perceived Ease } \\
\text { of Use of } \\
\text { eWOM }\end{array}$ & $\begin{array}{l}\text { - Ease of Use1 } \\
\text { - Ease of Use } 2 \\
\text { - Ease of Use3 } \\
\text { - Ease of Use4 } \\
\end{array}$ & $\begin{array}{l}0.62 \\
0.88 \\
0.87 \\
0.88 \\
\end{array}$ & 0.778 & 0.89 & 0.67 \\
\hline $\begin{array}{l}\text { Perceived } \\
\text { Usefulness of } \\
\text { eWOM }\end{array}$ & $\begin{array}{l}\text { - Usefulness1 } \\
\text { - Usefulness2 } \\
\text { - Usefulness3 }\end{array}$ & $\begin{array}{l}0.60 \\
0.88 \\
0.62\end{array}$ & 0.734 & 0.75 & 0.51 \\
\hline $\begin{array}{l}\text { Information } \\
\text { Adoption }\end{array}$ & $\begin{array}{l}\text { - Information } \\
\text { Adoption1 } \\
\text { - Information } \\
\text { Adoption2 } \\
\text { - Review Adoption1 }\end{array}$ & $\begin{array}{l}0.67 \\
0.88 \\
0.86\end{array}$ & 0.720 & 0.85 & 0.66 \\
\hline $\begin{array}{l}\text { Intention to } \\
\text { use eWOM for } \\
\text { Travel } \\
\text { Planning }\end{array}$ & $\begin{array}{l}\text { - Intention to travel1 } \\
\text { - Intention to travel2 } \\
\text { - Intention to travel3 }\end{array}$ & $\begin{array}{l}0.59 \\
0.78 \\
0.88\end{array}$ & 0.700 & 0.80 & 0.58 \\
\hline
\end{tabular}


Table 5: Discriminant validity test results

\begin{tabular}{|c|c|c|c|c|c|c|c|}
\hline & $\begin{array}{l}\text { Square } \\
\text { Root } \\
\text { of } \\
\text { AVE }\end{array}$ & $\begin{array}{l}\text { eWOM } \\
\text { Argument } \\
\text { Quality }\end{array}$ & $\begin{array}{l}\text { eWOM } \\
\text { Credibility }\end{array}$ & $\begin{array}{l}\text { Perceived } \\
\text { Ease of } \\
\text { Use of } \\
\text { eWOM }\end{array}$ & $\begin{array}{l}\text { Perceived } \\
\text { Usefulness } \\
\text { of eWOM }\end{array}$ & $\begin{array}{c}\text { Information } \\
\text { Adoption }\end{array}$ & $\begin{array}{c}\text { Intention } \\
\text { to use } \\
\text { eWOM } \\
\text { for } \\
\text { Travel } \\
\text { Planning } \\
\end{array}$ \\
\hline $\begin{array}{l}\text { eWOM } \\
\text { Argument } \\
\text { Quality }\end{array}$ & 0.71 & 1 & & & & & \\
\hline $\begin{array}{c}\text { eWOM } \\
\text { Credibility }\end{array}$ & 0.78 & $0.68 *$ & 1 & & & & \\
\hline $\begin{array}{l}\text { Perceived } \\
\text { Ease of Use } \\
\text { of eWOM }\end{array}$ & 0.82 & $0.61 *$ & $0.56 *$ & 1 & & & \\
\hline $\begin{array}{l}\text { Perceived } \\
\text { Usefulness } \\
\text { of eWOM }\end{array}$ & 0.71 & $0.49 *$ & $0.57 *$ & $0.44 *$ & 1 & & \\
\hline $\begin{array}{c}\text { Information } \\
\text { Adoption }\end{array}$ & 0.81 & $0.60 *$ & $0.68 *$ & $0.55 *$ & $0.27 *$ & 1 & \\
\hline $\begin{array}{c}\text { Intention to } \\
\text { use eWOM } \\
\text { for Travel } \\
\text { Planning }\end{array}$ & 0.76 & $0.58 *$ & $0.62 *$ & $0.62 *$ & $0.49 *$ & $0.61 *$ & 1 \\
\hline
\end{tabular}

Note: $*$ denotes correlation is significant at the 0.05 level (2-tailed) 
Table 6: SEM results and hypotheses testing

\begin{tabular}{|l|c|c|c|l|}
\hline & Hypothesis & $\gamma$ & $\begin{array}{c}\mathrm{p}- \\
\text { value }\end{array}$ & Inference \\
\hline $\begin{array}{l}\text { Perceived Usefulness of eWOM } \\
\rightarrow \text { Information Adoption }\end{array}$ & $\mathrm{H} 1 \mathrm{a}$ & .422 & 0.013 & Supported \\
\hline $\begin{array}{l}\text { Perceived Usefulness of eWOM mediates } \\
\text { Perceived Ease of Use of eWOM } \\
\text { Information Adoption }\end{array}$ & $\mathrm{H} 1 \mathrm{~b}$ & - & 0.047 & Supported \\
\hline $\begin{array}{l}\text { Perceived Ease of Use of eWOM } \\
\rightarrow \text { Perceived Usefulness of eWOM }\end{array}$ & $\mathrm{H} 2 \mathrm{a}$ & .337 & 0.025 & Supported \\
\hline $\begin{array}{l}\text { Perceived Ease of Use of eWOM } \\
\rightarrow \text { Information Adoption }\end{array}$ & $\mathrm{H} 2 \mathrm{~b}$ & .520 & 0.001 & Supported \\
\hline $\begin{array}{l}\text { eWOM Argument Quality } \rightarrow \text { Perceived } \\
\text { Usefulness of eWOM }\end{array}$ & $\mathrm{H} 3$ & .371 & 0.015 & Supported \\
\hline $\begin{array}{l}\text { eWOM Credibility } \rightarrow \text { Perceived Usefulness } \\
\text { of eWOM }\end{array}$ & $\mathrm{H} 4$ & .500 & 0.008 & Supported \\
\hline $\begin{array}{l}\text { Information Adoption } \rightarrow \text { Intention to use } \\
\text { eWOM for Travel Planning }\end{array}$ & $\mathrm{H} 5$ & .885 & 0.001 & Supported \\
\hline
\end{tabular}

Note: $\gamma$ denotes standardized regression weights

Table 7: Multi-group SEM results based on gender

\begin{tabular}{|l|c|c|c|c|c|c|}
\hline & $\begin{array}{c}\text { Male } \\
\gamma\end{array}$ & $\begin{array}{c}\text { Female } \\
\gamma\end{array}$ & Differences & $\begin{array}{c}\text { Less than 2 } \\
\text { hours } \\
\gamma\end{array}$ & $\begin{array}{c}2 \text { hours } \\
\text { or more } \\
\gamma\end{array}$ & Differences \\
\hline $\begin{array}{l}\text { Perceived Usefulness of } \\
\text { eWOM } \\
\text { Adoption Information }\end{array}$ & 0.330 & $0.480^{*}$ & Significant & $.432^{*}$ & $.394^{*}$ & Significant \\
\hline $\begin{array}{l}\text { Perceived Ease of Use of } \\
\text { eWOM } \rightarrow \text { Perceived } \\
\text { Usefulness of eWOM }\end{array}$ & 0.285 & $0.429^{*}$ & Significant & .177 & $.537^{*}$ & Significant \\
\hline $\begin{array}{l}\text { Perceived Ease of Use of } \\
\text { eWOM } \rightarrow \text { Information } \\
\text { Adoption }\end{array}$ & $0.539^{*}$ & $0.424^{*}$ & Significant & $.568^{*}$ & $.446^{*}$ & Significant \\
\hline $\begin{array}{l}\text { eWOM Argument } \\
\text { Quality } \rightarrow \text { Perceived } \\
\text { Usefulness of eWOM }\end{array}$ & 0.312 & $0.364^{*}$ & Insignificant & $.292^{*}$ & $.306^{*}$ & Insignificant \\
\hline $\begin{array}{l}\text { eWOM Credibility } \\
\text { PPerceived Usefulness } \\
\text { of eWOM }\end{array}$ & $0.421^{*}$ & $0.554^{*}$ & Significant & $.530^{*}$ & $.497^{*}$ & Significant \\
\hline $\begin{array}{l}\text { Information Adoption } \\
\text { Intention to use eWOM } \\
\text { for Travel Planning }\end{array}$ & $0.882^{*}$ & $0.863^{*}$ & Significant & $.889^{*}$ & $.899^{*}$ & Insignificant \\
\hline
\end{tabular}

Note: $\gamma$ denotes standardized regression weights

* denotes significance at 0.05 